\title{
PENGARUH LATAR BELAKANG PENDIDIKAN GURU BIMBINGAN DAN KONSELING TERHADAP PELAKSANAAN LAYANAN PADA SISWA SMK NEGERI 1 BENAKAT
}

\author{
Embet $^{1}$, Edi harapan ${ }^{2}$, Ramtia Darma Putri ${ }^{3}$ \\ Universitas PGRI Palembang ${ }^{1}$ \\ Email: embetsaragih2020@gmail.com \\ Universitas PGRI Palembang ${ }^{2}$ \\ Email : ediharapan74@gmail.com \\ Universitas PGRI Palembang ${ }^{3}$ \\ Email: tyadhuarrma27@gmail.com
}

\begin{abstract}
ABSTRAK
Penelitian ini bertujuan untuk mengetahui pengaruh latar belakang pendidikan guru bimbingan dan konseling terhadap pelaksanaan layanan pada siswa SMK Negeri 1 Benakat. Populasi dari penelitian ini adalah guru di SMK Negeri 1 Benakat. Penentuan sampel dalam penelitian ini secara Totally Samplingsebanyak 3 orang guru bimbingan dan konseling di SMK Negeri 1 Benakat. Metode penelitian adalah kuantitatif. Teknik pengumpulan data dilakukan dengan menggunakan angket, dokumentasi, dan observasi. Teknik analisis data menggunakan rumus regresi linier sederhana. Dari hasil penelitian dapat disimpulkan bahwa nilai $t_{\text {hitung }}$ 4,426 sedangkan nilai $t_{\text {tabel }}=2,042$. Dengan demikian thitung $>t_{\text {tabel }}$ atau 4,426 >2,042 untuk taraf signifikan 5\%. Hipotesis yang berbunyi "ada pengaruh latar belakang pendidikan guru bimbingan dan konseling terhadap pelaksanaan layanan pada siswa SMK Negeri 1 Benakat" dapat diterima.
\end{abstract}

Kata Kunci : Latar Belakang Pendidikan, Guru Bimbingan dan Konseling, Layanan Bimbingan dan Konseling.

\section{THE BACKGROUND INFLUENCE OF GUIDANCE AND CONSELING TEACHER'S EDUCATION ON PERFORMING SERVICESIN THE COUNTRY'S HIGH SCHOOL 1 BENAKAT}

\begin{abstract}
The study is aimed at recognizing the background influence the guidance andcounseling teacher's education on performing services on public SMK students. The population of this research is teachers in the country of 1 people. The fact that the sample in this study is totally sampling as many as 3 people guidance and counseling teachers in the country 1 council. The research method is quantitative. Data collection techniques are done using angkets, documentation, and observation. Data analysis techniques using simple linear regression formulas. Research suggests that the value of 4.426 and the value of ttabel $=2.042$. Thus thitung $>$ table or $4.426>2.042$ to a degree of significant 5\%. A hypothesis that says "there is a background influence on teachers'
\end{abstract}


education and counseling on performing services on country 1 st student council" is acceptable.

Keywords: Educational Background, Guidance And Counseling Teachers, Guidance Services And Counseling.

\section{PENDAHULUAN}

Peran guru dalam proses kemajuan pendidikan sangatlah penting. Guru merupakan salah satu faktor utama bagi terciptanya generasi penerus bangsa yang berkualitas, tidak hanya dari sisi intelektulitas saja melainkan juga dari tata cara berperilaku dalam masyarakat. Oleh karena itu tugas yang diemban guru tidaklah mudah. Guru yang baik harus mengerti dan memahami hakekat sejati seorang guru.

Guru menurut Undang-undang nomor 14 Tahun 2015 yaitu Guru adalah pendidik profesional yang memiliki tugas utama mendidik, mengajar, membimbing, mengarahkan, melatih, menilai dan mengevaluasi peserta didik pada pendidikan anak usia dini melalui jalur formal pendidikan dasar dan pendidikan menengah. Guru selalu berkecimpung dengan dunia pendidikan dan proses belajar mengajar.

\section{LANDASAN TEORI}

Menurut Undang-Undang Sisdiknas No. 20 Tahun 2013 yang dimaksud dengan pendidikan adalah usaha sadar dan terencana untuk mewujudkan suasana belajar dan proses pembelajaran agar peserta didik secara aktif mengembangkan potensi dirinya untuk memiliki kekuatan spiritual keagamaan, pengendalian diri, kepribadian, kecerdasan, akhlak mulia, serta keterampilan yang diperlukan dirinya, masyarakat, bangsa dan negara. Pendidikan diharapkan muncul generasi penerus bangsa yang berkualitas dan mampu menyesuaikan diri untuk hidup bermasyarakat, berbangsa dan bernegara. Peningkatan kualitas pendidikan akan berkaitan erat dengan peningkatan kompetensi profesional guru, dengan harapan semakin profesional seorang guru maka mutu pendidikan akan meningkat. Guru dituntut secara profesional untuk terus mengembangkan diri agar dapat mengikuti perkembangan yang cepat dalam bidang ilmu pengetahuan dan teknologi. Guru 
yang profesional adalah mereka yang secara konsisten memiliki kompetensi yang diperlukan untuk menyelesaikan tugasnya.

Berdasarkan peraturan perundangan guru Bimbingan dan Konseling (selajutnya disingkat BK) atau yang juga disebut konselor telah ditetapkan sebagai pendidik profesional. Atas dasar ketentuan ini maka akan terdapat berbagai konsekuensi yang menyertainya. Mulai dari persyaratan-persyaratan yang harus dipenuhi terutama yang berkaitan dengan kualifikasi pendidikan yang harus dimilikinya dan pengakuan legalistik atas penguasaan kompetensi yang dipersyaratkan oleh lembaga atau institusi berwenang yang ditunjuk oleh pemerintah (Kosasih\&Seotjipto, 2013:32).

Selanjutnya, pemenuhan kualifikasi pendidikan berupa kepemilikan ijazah Sarjana Strata Satu (S1) dalam bidang Bimbingan dan Konseling dari program studi yang terakreditasi oleh lembaga akreditasi yang sah. Sedangkan pengakuan atas penguasaan kompetensi baik yang berupa enabling competencies (kompetensi prasyarat) maupun performance competencies (kompetensi tampilan kinerja) dilakukan melalui pendidikan profesi dalam kurun waktu tertentu yang diakhiri dengan uji kompetensi. Jika berhasil dalam uji kompetensi yang bersangkutan akan memperoleh sertifikat profesi guru BK sebagai penanda bahwa pemegangnya telah dinyatakan professional.

Lebih lanjut setelah memenuhi ketentuan itu, ketika guru BK bekerja juga harus mengikuti prosedur atau alur kerja sebagai dasar pedoman dalam bekerjanya. Guru BK harus bekerja berdasar pada teori, paradigma, pendekatan, maupun teknik yang telah ada dan relative baku. Tahapan dalam pelaksanaan program Guru Bimbingan dan Konseling mengikuti cara tertentu seperti melalui tahap planning, designing, implementing, evaluating, and enhancing (Gysbers and Henderson dalam Prayitno, 2013:54).

Namun demikan bukan berarti seorang guru BK harus terpasung dengan ketentuan secara monoton dengan tanpa memiliki keleluasaan melakukan inovasi. Justru seiring dengan pengalaman di lapangan diharapkan melalui kajian, penelitian tindakan bimbingan, diskusi dengan sejawat dan atasan serta ekspertis dapat tercipta teknik-teknik baru yang memungkinkan hasil layanan bimbingan kepada peserta didik menjadi lebih berhasil dan berdaya guna. Untuk menjamin 
bahwa peserta didik mendapatkan layanan bimbingan dan konseling yang berkualitas, seorang guru BK dalam bekerjanya harus selalu mengindahkan dan mematuhi kode etik yang ditetapkan oleh organisasi profesi.

Selalu mematuhi ketentuan yang termuat dalam kode etik. Sikap, tindakan apakah yang harus ditunjukkan dan dilakukan, juga harus pula menghindari halhal apakah yang tidak diperbolehkan dalam bekerjanya. Hal ini semata-mata demi kepentingan, dan pemenuhan hak yang ada pada peserta didik untuk mendapatkan layanan terbaik.

Berdasarkan observasi awal di SMK Negeri 1 Benakat diketahui bahwa jumlah guru yang mengampu BK sebanyak tiga orang, namun latar belakang pendidikan guru yang mengampu atau membidangi BK masih memiliki latar belakang Strata Satu Bimbingan dan Konseling hanya satu orang, sedangkan dua orang lainnya masih memiliki latar belakang pendidikan Strata Satu Pendidikan Olahraga, dan Pendidikan Bahasa Indonesia. Hal ini berdampak pada layanan yang diberikan, dimana layanan yang diberikan hanya ketika siswa menghadapi masalah di sekolah. Selain itu, Pelaksanan pemberian layanan BK tidak efektif karena tidak sesuai dengan sistematika/tahapan konseling, karena latar belakang pendidikan guru yang berbeda yang tidak memahaminya. Oleh karena itu, latar belakang pendidikan yang dimiliki oleh guru BK sangat penting dalam pelaksanaan layanan.

Bimbingan dan konseling merupakan salah satu kesatuan yang berasal dari dua kata yaitu bimbingan dan konseling. Kegiatan bimbingan dan konseling senantiasa dilaksanakan di sekolah untuk mengatasi siswa yang bermasalah.

Bimbingan merupakan sebuah proses yang harus dilalui oleh sejumlah individu yang memerlukan perubahan atau pengembangan diri yang lebih positif, bimbingan dilakukan oleh seseorang konselor yang profesional dibidangnya agar bimbingan tersebut dapat berjalan dengan baik dan optimal.

Menurut Lefever dalam Prayitno (2013:94), bimbingan adalah bagian dari proses pendidikan yang teratur dan sistematik guna membantu pertumbuhan anak muda atas kekuatannya dalam menentukan dan mengarahkan hidupnya sendiri, yang pada akhirnya ia dapat memperoleh pengalaman-pengalaman yang dapat memberikan sumbangan yang berarti bagi masyarakat. 
Sementara Nurihsan (2014:7), mengemukakan bahwa bimbingan merupakan upaya pemmbimbing untuk membantu mengoptimalkan individu. Sedangkan menurut Sukardi, (2010:36), bimbingan adalah sebagai berikut "Suatu proses pemberian bantuan kepada individu yang dilakukan secara berkeseinambungan supaya individu tersebut dapat memahami dirinya sendiri, sehingga dia sanggup mengarkan dirinya dan dapat bertindak secara wajar, sesuai dengan tuntutan dan keadaan lingkungan sekolah, keluarga, dan masyarakat dan kehidupuan pada umumnya."

Dengan demikian berdasarkan pendapat di atas dapat penulis simpulkan bahwa bimbingan merupakan bantuan yang diberikan kepada seseorang atau individu dalam rangka upaya menemukan pribadi, mengenal lingkungan, dan merencanakan masa depan, yang setiap keputusan akhir tetap individu itu sendiri yang memutuskannya (menentukan pilihan).dengan itu dapat di ketahui apa yang menjadi tujuan bimbingan itu sendiri.

Konseling pada dasarnya dilakukan secara individual yaitu antara klien dan konselor, yang dalam hal ini antara siswa dan guru bimbingan dan konseling yang ada di sekolah.

Menurut Walgito (2014:7), konseling adalah bantuan yang diberikan kepada individu dalam memecahkan masalah kehidupannya dengan wawancara dan dengan cara yang sesuai dengan keadaan yang dihadapi individu untuk mencapai kesejahteraan hidup. Lebih lanjut menurut Salahudin (2016:15), konseling adalah usaha untuk membantu konseli/klien secara tatap muka dengan tujuan agar klien dapat mengambil tanggung jawab sendiri terhadap berbagai persoalan atau masalah khusus. Dengan kata lain, teratasinya masalah dihadapi oleh konseli/klien. Sedangkan menurut Nurihsan (2014:11), konseling merupakan salah satu bentuk hubugan yang bersifat membantu.

Berdasarkan pendapat di atas, maka dapat disimpulkan bahwa konseling merupakan suatu upaya bantuan yang dilakukan dengan empat mata atau tatap muka antara konselor dan klien yang berisi usaha yang alras, unik, manusiawi, yang dilakukan dalam suasana keahlian dan yang didasarkan atas norma-norma yan berlaku, agar klien memperoleh konsep diri dan kepercayaan diri sendiri 
dalam memperbaiki tingkah lakunya pada saat ini dan mungkin pada masa yang akan datang.

Tujuan bimbingan sangat perlu diketahui oleh para guru bimbingan dan konseling, mengingat hal ini akan memberikan gambaran tentang tujuan yang akan dicapai dalam mengatasi siswa yang bermasalah.

Menurut Hamrin dalam Prayitno (2013:112) tujuan bimbingan adalah "Untuk membantu individu membuat pilihan-pilihan, penyesuaian-penyesuaian, interpretasi-interpretasi dalam hubungannya dengan situasi-situasi tertentu".

Sedangkan menurut Nurihsan (2014:8), tujuan pemberian layanan bimbingan ialah agar individu dapat :

1) Merencanakan keiatan penyelesaian studi, perkembangan karir, serta kehidupan pada masa yang akan datang.

2) Mengembangkan seluruh potensi dan kekuatan yang dimilikinya seoptimal mungkin

3) Menyesuaikan diri dengan lingkungan pendidikan, lingkungan masyarakat, serta lingkungan kerjanya, dan

4) Mengatasi hambatan serta kesulitan yang dihadapi dalam studi, penyesuaian dengan lingkungan pendidikan, masyarakat ataupun lingkungan kerja.

Berdasarkan beberapa pendapat di atas dapat di simpulkan bahwasanya tujuan dari bimbingan itu sendiri adalah untuk membantu individu dalam mengenal dirinya sendiri serta membantu setiap permasalahan yang sedang di hadapi oleh individu agar mencapai kesejahteraan hidup yang optimal.

Fungsi bimbingan tidak hanya bagi siswa yang bermasalah akan tetapi juga terhadap fungsi perkembangan yang nantinya akan mempengaruhi proses prilaku dan tingkah laku siswa.

Fungsi dapat dikelompokkan menjadi empat fungsi pokok antara lain :

1. Fungsi Pemahaman

2. Fungsi Pencegahan

3. Adaptasi

4. Fungsi Penyesuaian. 
Fungsi Pemahaman dimaksudkan pemahaman tentang diri klien beserta permasalahannya oleh klien sendiri dan oleh pihak- pihak yang akan membantu klien, serta pemahaman tentang lingkungan klien oleh klien Prayitno (2013:197).

Fungsi Pencegahan (Preventif). Layanan bimbingan dapat berfungsi pencegahan artinya merupakan usaha pencegahan terhadap timbulnya masalah. Dalam fungsi pencegahan ini layanan yang diberikan berupa bantuan bagi para siswa agar terhindar dari berbagai masalah yang dapat menghambat perkembangannya (Sukardi, 2008:42).

Fungsi Adaptasi yaitu fungsi membantu para pelaksana pendidikan, khususnya guru/dosen, widyaiswara, dan wali kelas untuk mengadaptasikan program pendidikan terhadap latar belakang pendidikan, minat, kemampuan, dan kebutuhan individu (Nurihsan, 2014:9).

Fungsi Penyesuaian. Menurut Winkel dan Hastuti (2016:67), fungsi penyesuaian, yaitu fungsi bimbingan dalam membantu siswa menemukan cara menempatkan diri secara tepat dalam berbagai keadaan dan situasi yang dihadapi. Misalnya, siswa haurs dibantuk untuk bergaul secara memuaskan dengan menentukan sikap di tengah-tengah kehidupan keluarga (adjustment).

Fungsi-fungsi ini perlu di pahami dan di jalankan oleh setiap konselor di lembaga-lembaga pendidikan, agar setiap permasalahan siswa dapat terentaskan dan menjadikan siswa lebih baik dalam segalah hal tidak hanya terfokus pada masalah pendidikan saja, sehingga perlu berpegang pada prinsip-prinsip bimbingan itu sendiri.

Keberadaan konselor dalam sistem pendidikan nasional dinyatakan sebagai salah satu kualifikasi pendidik, sejajar dengan kualifikasi guru, dosen, pamong belajar, tutor, widyaiswara, fasilitator, dan instruktur (UU No. 20 Tahun 2003 Pasal 1 Ayat 6). Masing-masing kualifikasi pendidik, termasuk konselor, memiliki keunikan konteks tugas dan ekspektasi kinerja. Standar kualifikasi akademik dan kompetensi konselor dikembangkan dan dirumuskan atas dasar kerangka pikir yang menegaskan konteks tugas dan ekspektasi kinerja konselor.

Konteks tugas konselor berada dalam kawasan pelayanan yang bertujuan mengembangkan potensi dan memandirikan konseli dalam pengambilan keputusan dan pilihan untuk mewujudkan kehidupan yang produktif, sejahtera, 
dan peduli kemaslahatan umum. Pelayanan dimaksud adalah pelayanan bimbingan dan konseling. Konselor adalah pengampu pelayanan ahli bimbingan dan konseling, terutama dalam jalur pendidikan formal dan nonformal.

Ekspektasi kinerja konselor dalam menyelenggarakan pelayanan ahli bimbingan dan konseling senantiasa digerakkan oleh motif altruistik, sikap empatik, menghormati keragaman, serta mengutamakan kepentingan konseli, dengan selalu mencermati dampak jangka panjang dari pelayanan yang diberikan.

Sosok utuh kompetensi konselor mencakup kompetensi akademik dan profesional sebagai satu keutuhan. Kompetensi akademik merupakan landasan ilmiah dari kiat pelaksanaan pelayanan profesional bimbingan dan konseling. Kompetensi akademik merupakan landasan bagi pengembangan kompetensi profesional, yang meliputi:

(1) Memahami secara mendalam konseli yang dilayani,

(2) Menguasai landasan dan kerangka teoretik bimbingan dan konseling,

(3) Menyelenggarakan pelayanan bimbingan dan konseling yang memandirikan, dan

(4) Mengembangkan pribadi dan profesionalitas konselor secara berkelanjutan (Prayitno, 2013:43).

Unjuk kerja konselor sangat dipengaruhi oleh kualitas penguasaan keempat komptensi tersebut yang dilandasi oleh sikap, nilai, dan kecenderungan pribadi yang mendukung. Kompetensi akademik dan profesional konselor secara terintegrasi membangun keutuhan kompetensi pedagogik, kepribadian, sosial, dan profesional.

Pembentukan kompetensi akademik konselor ini merupakan prosespendidikan formal jenjang strata satu (S-1) bidang Bimbingan dan Konseling, yang bermuara pada penganugerahan ijazah akademik Sarjana Pendidikan (S.Pd) bidang Bimbingan dan Konseling. Sedangkan kompetensi profesional merupakan penguasaan kiat penyelenggaraan bimbingan dan konseling yang memandirikan, yang ditumbuhkan serta diasah melalui latihan menerapkan kompetensi akademik yang telah diperoleh dalam konteks otentik Pendidikan Profesi Konselor yang berorientasi pada pengalaman dan kemampuan praktik lapangan, dan tamatannya memperoleh sertifikat profesi 
bimbingan dan konseling dengan gelar profesi Konselor, disingkat Kons (Sukardi, 2008:43).

\section{METODOLOGI PENELITIAN}

Metode penelitian adalah suatu cara yang digunakan oleh peneliti dalam mengumpulkan data penelitiannya (Arikunto, 2010:160). Metode yang digunakan dalam penelitian ini adalah metode kuantitatif.

\section{HASIL PENELITIAN DAN PEMBAHASAN}

Hasil dari penelitian ini berhubungan langsung dengan variabel penelitian yaitu Pengaruh Latar Belakang Pendidikan Guru Bimbingan Dan Konseling Terhadap Pelaksanaan Layanan Pada Siswa SMK Negeri 1 Benakat. Hasil penelitian ini diperoleh dari guru sebanyak 3 orang dan cara mengumpulkan data penelitian melalui angket guna mengetahui pengaruh latar belakang pendidikan guru bimbingan dan konselilng terhadap pelaksanaan layanan. Data hasil penelitian yang diperoleh tersebut selanjutnya dianalisis guna menjawab permasalahan dalam penelitian.Prayitno (2013:253), menjelaskan bahwa layanan BK mencakup sembilan jenis layanan, yaitu:

1. Layanan Orientasi

Layanan orientasi yaitu layanan konseling yang memungkinkan klien memahami lingkungan yang baru dimasukinya untuk mempermudah dan memperlancar berperannya klien dalam lingkungan baru tersebut.

2. Layanan Informasi

Layanan informasi yaitu layanan konseling yang memungkinkan klien menerima dan memahami berbagai informasi yang dapat dipergunakan sebagai bahan pertimbangan dan pengambilan keputusan untuk kepentingan klien.

3. Layanan Penempatan dan Penyaluran

Layanan penempatan dan penyaluran yaitu layanan konseling yang memungkinkan klien memperoleh penempatan dan penyaluran yang sesuai dengan bakat dan kemampuan masing-masing. 


\section{Layanan Penguasaan Konten}

Layanan penguasaan konten yakni layanan konseling yang memungkinkan klien mengembangkan diri berkenaan dengan sikap dan kebiasaan belajar yang baik, materi pelajaran yang cocok dengan kecepatan dan kesulitan belajarnya, serta berbagai aspek tujuan dan kegiatan belajar lainnya.

5. Layanan Konseling Individual

Konseling individual adalah proses belajar melalui hubungan khusus secara pribadi dalam wawancara antara seorang konselor dan seorang konseli/klien. Konseli/klien mengalami kesukaran pribadi yang tidak dapat dipecahkan sendiri, kemudian ia meminta bantuan konselor sebagai petugas yang profesional dalam jabatannya dengan pengetahuan dan ketrampilan psikologi. Konseling ditujukan pada individu yang normal, yang menghadapi kesukaran dalam mengalami masalah pendidikan, pekerjaan dan sosial dimana ia tidak dapat memilih dan memutuskan sendiri. Dapat disimpulkan bahwa konseling hanya ditujukan pada individu-individu yang sudah menyadari kehidupan pribadinya.

6. Layanan Bimbingan Kelompok

Bimbingan kelompok dimaksudkan untuk mencegah berkembangnya masalah atau kesulitan pada diri konseli/klien. Isi kegiatan bimbingan kelompok terdiri atas penyampaian informasi yang berkenaan dengan masalah pendidikan, pekerjaan, pribadi, dan masalah sosial yang tidak disajikan dalam bentuk pelajaran.

7. Layanan Konseling Kelompok

Strategi berikutnya dalam melaksanakan program BK adalah konseling kelompok. Konseling kelompok merupakan upaya bantuan kepada peserta didik dalam rangka memberikan kemudahan dalam perkembangan dan pertumbuhannya. Selain bersifat pencegahan, konseling kelompok dapat pula bersifat penyembuhan. 
8. Layanan Mediasi

Layanan mediasi yakni layanan konseling yang memungkinkan permasalahan atau perselisihan yang dialami klien dengan pihak lain dapat terentaskan dengan konselor sebagai mediator.

9. Layanan Konsultasi

Pengertian konsultasi dalam program BK adalah sebagai suatu proses penyediaan bantuan teknis untuk konselor, orang tua, administrator dan konselor lainnya dalam mengidentifikasi dan memperbaiki masalah yang membatasi efektivitas peserta didik atau sekolah. konseling atau psikoterapi sebab konsultasi tidak merupakan layanan yang langsung ditujukan kepada klien, tetapi secara tidak langsung melayani klien melalui bantuan yang diberikan orang lain.

10. Layanan Advokasi

Layanan advokasi dalam konseling bermaksud mengentaskan klien dari suasana yang menghimpit dirinya karena hak-hak yang hendak dilaksanakan terhambat dan terkekang sehingga keberadaan, kehidupan perkembangannya, khususnya dalam bidang pendidikan tidak lancar, tertanggu, atau bahkan terhenti atau terputus (Prayitno, 2018:221).

\section{KESIMPULAN}

Berdasarkan kriteria tersebut, dinyatakan bahwa nilai $t_{\text {hitung }} 4,426$ sedangkan nilai $t_{\text {tabel }}=2,042$. Dengan demikian $t_{\text {hitung }}>t_{\text {tabel }}$ atau 4,426 >2,042 untuk taraf signifikan 5\%. Hipotesis yang berbunyi "ada pengaruh latar belakang pendidikan guru bimbingan dan konseling terhadap pelaksanaan layanan pada siswa SMK Negeri 1 Benakat” dapat diterima.

\section{DAFTAR PUSTAKA}

Arikunto, Suharsimi. 2010. ProsedurPenelitiansuatuPendekatanPraktekJakarta : RinekaCipta.

Kosasih \& Seotjipto. 2012. Pengantar Pendidikan. Jakarta: Rineka Cipta.

Muna, Khoirul. 2016. Pengaruh Latar Belakang Pendidikan Guru dan Pelatihan Keguruan terhadap Kompetensi Profesional Guru Sosiologi SMA Negeri dan 
Swasta di Kabupaten Kudus. Skripsi Universitas Negeri Yogyakarta: Tidak Dipublikasikan.

Nurihsan, Juntika Ahmad. 2014. Pengantar Bimbingan dan Konseling. Jakarta: Rineka Cipta.

Prayitno. 2013. Dasar-dasar Bimbingan dan Konseling. Jakarta: Rineka Cipta.

Riduwan. 2011. Penelitian untuk Peneliti. Jakarta: Erlangga.

Risnawati. 2015. Pengaruh Latar Belakang Pendidikan Guru Terhadap Kompetensi Profesional Guru. Skripsi Universitas Negeri Semarang: Tidak Dipublikasikan.

Salahudin. 2016. Bimbingan dan Konseling. Jakarta: Rineka Cipta.

Sudjana. 2015. Statistika Penelitian. Bandung: Tarsito.

Sugiyono. 2012. Statistik untuk Penelitian. Bandung : Alfabeta.

Sukardi, Ketut Dewa. 2010. Psikologi Perkembangan. Jakarta: Rineka Cipta.

Undang-Undang Sisdiknas No. 20 Tahun 2013 tentang Pendidikan Nasional.

Undang-undang nomor 14 Tahun 2015 tentang Guru Profesional.

Walgito. 2014. Psikologi Perkembangan. Jakarta: Rineka Cipta.

Winkel, W.S dan M.M. Sri Hastuti. 2016. Bimbingan dan Konseling di Institusi Pendidikan. Jakarta : Kencana. 